\title{
On Leptonereis glauca Clpde., and the Genus Leptonereis Kinberg.
}

\author{
By
}

\author{
L. N. G. Ramsay, M.A., B.Sc., \\ Carnegie Research Scholar, Christ's College, Cambridge. \\ With Plate 1 in the Text.
}

\section{INTRODUCTORY.}

In February of this year Mr. J. H. Orton collected a number of small nereids on the piles of a wharf at the Great Western Docks at Millbay, Plymouth. These he kindly handed over to me for identification, and, along with other material collected at Plymouth in March, they form the basis of this paper.

These nereids proved to be none other than the little-known Leptonereis glauca of Claparède, of which the only specimen hitherto recorded from the shores of this country was found by Major E. V. Elwes at Oddicombe $(8$, p. 351$)$ some years ago.

Claparède $(3$, p. 90$)$ described the species from specimens obtained by him at Naples about 1870. He gives a good description and figures, but no particulars as to its numbers or habitat. It was next met with by de St. Joseph, who found it commonly in dredgings at all depths on the coasts of Dinard (6,p. 246) in 1888. This authority described his specimens as a distinct species, naming it $L$. vaillanti. (I shall show later that the two are identical.) He observed also the male and female heteronereids, of which he gave excellent and detailed descriptions, with a number of figures.

Thenceforward, L. glauca was not met with so far as has been recorded, until 1909, when Major Elwes found his specimen, a male heteronereid, at Oddicombe.

In 1878, however, Langerhans (5, p. 279) had described under the name of Leonnates pusillus another small species of nereid which, as I hope to show, is very closely related to, if not identical with, the one under consideration. This species he found at Madeira, and he observed in an aquarium the change to the heteronereid form in both sexes. 
There can be little doubt that Leptonereis must occur commonly in many localities on the shores of this country and of the Continent in which its presence is not suspected, either for lack of observers or on account of its small size.

\section{GENUS LEPTONEREIS KINBERG, CHAR. EMEND.}

Proboscis furnished only with soft papillæ.

The notopodium and neuropodium rather deeply divided.

In the male heteronereid, the body is divided into three distinct regions, the middle region only being modified for swimming, while the posterior is marked by the appearance of peculiar fused setæ, not present in the nereid-form or in the female heteronereid.

Characters otherwise as in Nereis Lin.

Leptonereis glauda Claparède, Plate I, Figs. 1-10.

Leptonereis glauca Claparède, 3 , p. 90, Pl. 7, Figs. 3-3c.

" vaillanti de St. Joseph, 6, p. 246, Pl. 10, Figs. 113-123;

Pl. 11, Fig. 124.

, vaillanti Elwes, 8 , p. 351 .

,2 vaillanti McIntosh, 8, p. 264, Pl. 86, Figs. 9-9a.

? Leonnates pusillus Langerhans, 5, p. 279.

This little nereid occurs in some numbers on the piles of the wharf at the Great Western Docks. These are exposed at low water, and are covered with compound ascidians, sponges, various cœlenterates and other sedentary organisms, which, together with the muddy sediment which accumulates in such places, form a thick encrustation on the cement piles and wallings near low-water mark. In these congenial surroundings Leptonereis dwells. It also occurs in dredgings from Asia Shoal and the Cattewater, in the former of which localities the bottom consists of stones and mud, in the latter of soft mud.

Its small size and the resulting difficulty of distinguishing it from other small nereids, no doubt account for its having been hitherto overlooked. The short cephalic lobe, stout squat palpi, and short tentacles, peristomial and parapodial cirri, and peristomium, serve to distinguish it -once its appearance is known-from Nereis pelagica, small examples of which occur in the same localities, but for certainty the parapodia and proboscis must be examined under the microscope.

Several dozens of specimens in all were collected, and a number of these were examined in detail, as a basis for the following description. 
The length of the individuals ranges from $7 \mathrm{~mm}$. to $35 \mathrm{~mm}$., but the majority are about $25 \mathrm{~mm}$. long.

As to colour, I examined live specimens from all three localities, and these were practically colourless, except for blood-vessels and gut showing through the semi-transparent body-wall. In examination some months later, however, some specimens (preserved in alcohol) show a slight band of brownish granular pigment across the dorsum of each segment, becoming more marked towards the posterior end of the animal. This band of pigment is more or less continuous with glands which occur on the base of the parapods, rather like those of $N$. dumerilii.*

Specimens of average size have 55 to 60 pairs of parapods ; the greatest number noted was 66 , the smallest, in a specimen barely $9 \mathrm{~mm}$. long, 35 pairs.

The body is fairly stout, tapering gradually towards the posterior end. There is a tendency towards shortness in all the appendages. The general form will best be realized by a glance at the figures, which are taken from typical specimens (Plate I, Fig. 1).

These worms, when placed in spirit, usually die with the proboscis retracted, but $I$ succeeded in preventing its retraction in about a dozen specimens, obtained during my stay at Plymouth, by means of a pin pressed behind the head while spirit was poured over the creature. (This immensely facilitates the examination of small nereids.) The proboscis is short and stout; the maxillary division is quite smooth, but the basal division possesses on the ventral side a row of 5 to 9 minute, soft, conical papillæ, perfectly colourless, in a transverse, even-spaced row towards the anterior margin. These correspond in position to paragnaths of groups VII, VIII. On the dorsal surface of the basal division a single larger papilla of similar nature (corresponding to VI) exists on each side. These papillæ are small and very inconspicuous. It is very difficult to distinguish them at all except when seen in profile, or when the light upon them falls at a suitable angle. Fig. 1 shows in profile the two outer papillæ of the ventral row.

Neither Claparède nor de St. Joseph observed any trace of such papillæ in the specimens from Naples and Dinard, but the Plymouth examples agree so completely otherwise with those, that one is inclined to

* Later, in December, 1913, Mr. Orton kindly sent to me at Cambridge a number of living specimens from the Great Western Docks. In the living state these were of a dull orange tint over most of the body, due to the internal organs showing through the transparent body-wall. Towards the anterior end there was a slight dull greenish pigmentation of the skin, strongest on the head and adjacent segments, but hardly noticeable in most specimens. This pigment is shown up more clearly just after fixation when the body has become opaque. 
think that the papillæ must have escaped observation in the other cases.

Their presence, of course, rather upsets the characterisation of the genus, which has hitherto been based solely on the total absence of paragnaths or papillæ!

A remarkable feature was exhibited by a number of specimens collected on 20th March. These bore on the proboscis four patches of a jet-black colour, radiating outwards from the bases of the jaws, in the everted proboscis, towards the areas where groups II and IV of the paragnaths would, if present, occur. These black marks appeared to consist of a deposit of opaque pigment beneath the cuticle. Fig. 1 is taken from a typical specimen, and shows the two dorsal patches. Of twelve specimens collected on this date, eight showed these patches strongly developed, while the remainder exhibited no trace of them.

The black marks were still present when the specimens were re-examined after lying for some weeks in alcohol and formol, but by October, 1913, all traces of them had disappeared. Fortunately, however, one specimen had been mounted in balsam at the earlier date, and in this (the specimen figured) the black is perfectly preserved. Further investigation of its nature is desirable. The only other specimens which I examined in a fresh state had the proboscis inverted; the rest of the material had been lying in spirit for some months.*

The parapodia of Leptonereis have been described in detail by St. Joseph, but I have thought it useful to figure these again, as they are the chief means of identification. (St. Joseph's figures are rather grotesque. $\dagger$ ) They do not differ from the typical nereis-form of parapod except in that their noto- and neuropodia are more deeply and widely separated than usual. They are approximately similar from end to end of the body. The noto-cirri are rather short, usually slightly overreaching the ligule; a slight increase in relative length of the cirri usually takes place in the posterior half of the body.

The setæ, which have been figured by Claparède, St. Joseph, and McIntosh, have the typical nereid arrangement, thus :-

Notopodial bundle, homogomph spinigers.

Upper neuropodial bundle $\left\{\begin{array}{l}\text { homogomph spinigers (above). } \\ \text { heterogomph falcigers (below). }\end{array}\right.$

Lower neuropodial bundle $\left\{\begin{array}{l}\text { heterogomph spinigers (above). } \\ \text { heterogomph falcigers (below). }\end{array}\right.$

* The everted probosces of more than a dozen of the living specimens received in December, 1913, showed on examination no trace of these black patches.

† Claparède's single figure of a parapod is also unnatural. 
St. Joseph (6, p. 247) notes that from the 13 th to the 4 th last segment, the spinigers of the notopodial bundle are replaced by others, similar, but with a much longer terminal appendage. This appears to be the case, too, in some at least of the Plymouth specimens, although the change seems to occur posterior to the 13th segment. I have not paid much attention to this point. He also states that homogomph as well as heterogomph spinigers occur in the lower neuropodial bundle. This I have not found to be the case.

Among the material collected by Mr. Orton on 25th February is a male heteronereis, apparently in the fully developed condition, and two other males at earlier stages of development.

St. Joseph (6) has described both the male and female heteronereid forms in detail. Claparède did not meet with either.

The above-mentioned male agrees very well with St. Joseph's description. It is $12.5 \mathrm{~mm}$. long, with 58 pairs of parapodia. The noto-cirri of the first seven pairs of parapodia are much swollen (Fig. 7). The change to the swimming-parapod occurs between the 14th and 15th pairs (St. Joseph found it to occur between the 15th and 16th pairs-the variation is unimportant). In the 43rd to 45 th pairs a transition towards the form of the third region occurs, the cirri and lobes becoming shorter and smaller, and the paddle-setæ decreasing in number.

The third region may be reckoned as commencing at the 44th pair, where the peculiar, large, simple setæ, figured by St. Joseph, commence. These are from one to three in number, and continue till the last setigerous segment. They are, I believe, to be regarded simply as derived from normal heterogomph falcigers by the fusion of the appendage with its socket. Ground for this belief is afforded by the analogy of the large bristles which occur in the posterior regions of Nereis pelagica and $N$. agassizi. In these the appendages are in some cases completely free, in others totally fused with the shaft.

Several females of the nereis-form, obtained on 20th March, were filled with ova. These are of very large relative size (0.24 mm. diameter).

The synonymy at the head of this section requires some explanation.

St. Joseph in his detailed and excellent account of Leptonereis vaillanti never refers to the possibility of this species being identical with Claparède's. He does not indicate any points of difference between the two species, and indeed, the only mention he makes of $L$. glauca is to say that the setæ of vaillanti are exactly similar to those figured by Claparède for the Mediterranean form. 
Comparison of the descriptions and figures published by these two authors leaves us with the following points of difference :-

(a) The Dinard specimens differ slightly in colour.

(b) Their noto-cirri are shorter.

The general form of the head and its appendages, the proboscis and jaws, the peristomial cirri, the parapodia (except for the noto-cirri), the setæ, the dimensions of the whole animal and number of segments-all are identical in the two.

As to the points of difference, $(a)$ hardly amounts to more than the fact that the Mediterranean specimens were more strongly pigmented than those from Dinard. The Plymouth ones, it appears, are still less so.

Then coming to $(b)$ one may note that the noto-cirri of the Plymouth specimens are almost intermediate between those of St. Joseph's and those of Claparède's. It does not seem that much importance should be attached to this point.

Secondly, I have come to the conclusion that Langerhans' Leonnates pusillus from Madeira is at least very closely related to Claparède's Leptonereis glauca. Langerhans' description and figures leave no doubt that the two species are of the same genus (in view of the presence of papillæ on the proboscis to Leptonereis). In Leonnates pusillus a papilla is present in area II on each side, in addition to those on the basal ring (these are only visible "bei sehr genauem Zusehen"). Also the peristomial segment apparently was distinctly longer than in Leptonereis glauca. Many examples showed a large yellow spot on the cephalic lobe; this, however, was not always present.

In other respects Leonnates pusillus is identical with Leptonereis glauca. Langerhans kept some specimens in captivity for some time and witnessed the change to the heteronereid form, in both male and female. His observations on these agree essentially with St. Joseph's. The large, brown setæ appeared in the same way in the posterior eleven pairs of parapodia of the male.

Langerhans concludes his description of this species with the suggestion that an examination of fresh material will show that in species such as Leptonereis glauca and $L$. cebuensis the proboscis is furnished with papillæ similar to those of Leonnates pusillus. After a lapse of thirtyfive years his prediction has been fulfilled. 


\section{HISTORY AND SYSTEMATIC POSITION OF THE GENUS.}

Kinberg (2, p. 179), in 1865, "created" the family Niconidea to contain those nereids in which the proboscis is devoid of papillæ, whether hard (paragnaths) or soft.

This family contained three genera, distinguished thus :-

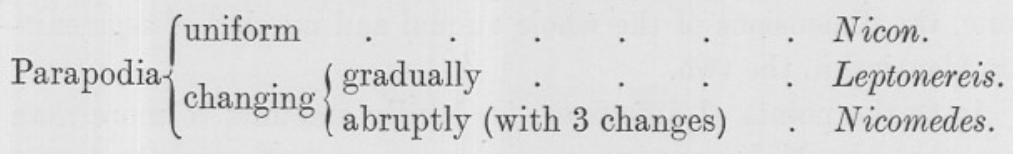

In these three genera he enumerated eight species, all new to science, from the east and west coasts of South America, and from Tahiti. None of these species is described in sufficient detail to be recognisable, and only one is figured [(1, Taf. XX, Fig. 7), Leptonereis lavis, n.sp., from Guayaquil].

Claparède (3, p. 90) united Kinberg's three genera under the name of Leptonereis, which he ranked as a sub-genus of Nereis, Linn. s. str. He chose the name Leptonereis on account of its convenience as a sub-generic name, and because it was the only one of the three genera which Kinberg had figured.

Claparède did not further characterise Leptonereis, but apparently simply accepted Kinberg's definition of the " family " Niconidea, namely, total absence of paragnaths or papillæ from the proboscis. Further he described Nereis (Leptonereis) glauca, a new species of which he apparently found several specimens in the Gulf of Naples, although in his "Annélides Chétopodes du Golfe de Naples" he gives absolutely no information as to its occurrence or habitat. He also figured the head and anterior segments, proboscis, a parapod, and setæ (most of his figures are good, although a little "artificial" in appearance).

In 1878 Grube described L. cebuensis from the Philippine Islands, and in the same year Langerhans published his account of Leonnates pusillus. Ten years later St. Joseph brought out his account of the annelids of the coasts of Dinard.

Grube and St. Joseph both followed Claparède in regarding Leptonereis as a sub-genus of Nereis, but McIntosh ranks it as a separate genus, differing from Nereis Lin. in the absence of paragnaths and in the deeply divided rami of the parapodia.

My own view, based on the examination of a large amount of material in all the groups of the genus Nereis, and in Leonnates and Leptonereis, is that the last-named should be ranked as a genus distinct from both 
the others. These three genera are, however, more closely related to one another than to any of the remaining genera of Nereidæ (i.e. Lycastis, Ceratocephale, Tylorrhynchus, Dendronereis, and Micronereis).

\section{SURVEY OF THE GENUS LEPTONEREIS.}

For generic characters (emended) see above, p. 245.

1. Leptonereis glaUca Claparède, 1870.

L. vaillanti, de St. Joseph, 6.

Range : English Channel.

2. Leptonereis PUsillus Langerhans, 1878.

Leonnates pusillus Langerhans, 5.

Very closely allied to the preceding species, if not identical (see above, p. 249).

Range: Madeira.

3. Leptonereis cebuensis Grube, 1878.

Grube's description of this species is unfortunately not accompanied by any figures.

Range: Philippine Islands.

4. Leptonereis Lævis Kinberg, 1865.

This species must remain rather uncertain, as Kinberg's description is very brief. The figures of anterior region and proboscis, a parapodium, and the setæ, are fairly good. The palps and tentacular cirri are longer than in L. glauca.

Range: Guayaquil (Ecuador).

[Kinberg did not figure any of the other seven species which he described under the genera Nicon and Nicomedes, and his descriptions are so brief as to be of little value for purposes of identification. The only one of these which has been met with again is Nicon loxechini, from the Straits of Magellan. In this case Ehlers has employed the name Nereis loxechini Kinberg for a species of which a single small specimen was collected by the German Deep-Sea Expedition at St. Paul Island $\left(38^{\circ} 40^{\prime}\right.$ S., $77^{\circ} 38^{\prime}$ E.), in the southern Indian Ocean. Ehlers unfortunately does not figure this specimen, nor does he describe it fully, so that there is considerable doubt as to whether it should be assigned to the genus Leptonereis. The Nereis eugenice Kinberg of Ehlers, although founded on Kinberg's Nicon eugenia, is a true Nereis.] 


\section{BIBLIOGRAPHY OF THE GENUS LEPTONEREIS.}

1. Kinberg, J. G. H. Fregatten Eugenies Resa, Zool. VII. Annulater. Stockholm, 1865. (Republished 1910.)

2. Kinberg, J. G. H. "Annulata Nova," Ofvers. K. Vet-Akad. Förh., 1865.

3. Claparède, E. "Annélides Chétopodes du Golfe de Naples, Suppl." Mém. Soc. de Phys. et d'Hist. Nat. de Genève, T. XX, 1870.

4. Grube, E. "Annulata Semperiana." Mém. Ac. Imp. Sci. de St. Pétersbourg, VII ${ }^{\mathrm{e}}$ Ser., T. XXV, No. 8, 1878.

5. Langerhans, P. "Die Wurmfauna von Madeira, II." Zeitschr. $f$. Wiss. Zool., XXXIII, 1878.

6. St. Joseph, Baron De. "Annélides Chétopodes des Côtes de Dinard" (pte. ii.). Ann. des Sci. Nat. (7e), V, 1888.

7. Ehlers, E. "Bodensässigen Anneliden," Wiss. Ergebn. des Deutschen Tiefsee-Exp., Bd. XVI, Lfg. i., Jena, 1908.

8. Elwes, E. V. "Littoral Polychæta of Torquay." Journ. Mar. Biol. Ass., VIII, 1909.

9. McIntosh, W. C. "The British Annelids." The Ray Society, London, 1910, Vol. II, pt. ii.

\section{EXPLANATION OF PLATE.}

Leptonereis glauca Clap. Plymouth, 1913.

Fig. 1. Anterior region, with proboscis extended, $\times 23$.

„2. Posterior extremity (from above), $\times 23$.

Figs. 3-5. Parapodia of immature form.

Fig. 3. 2nd R., anterior view, $\times 25$.

„4. 12th L., anterior view, $\times 25$.

" 5. 34th L., anterior view (total 59 pairs), $\times 25$.

"6. 41st L. ( $q$ nereid with ova), anterior view (total about 60 pairs), $\times 25$.

\section{Figs. 7-10. Male Heteronereis.}

Fig. 7. 5th R., posterior view, $\times 35$.

„8. 30th R., anterior view, $\times 47$.

"9. 48th R., posterior view (total 58 pairs), $\times 35$.

", 10. Neuropodium from the posterior region, showing one of the large fused setæ half-grown, not as yet projecting from the parapodium (posterior view), $\times 145$. 

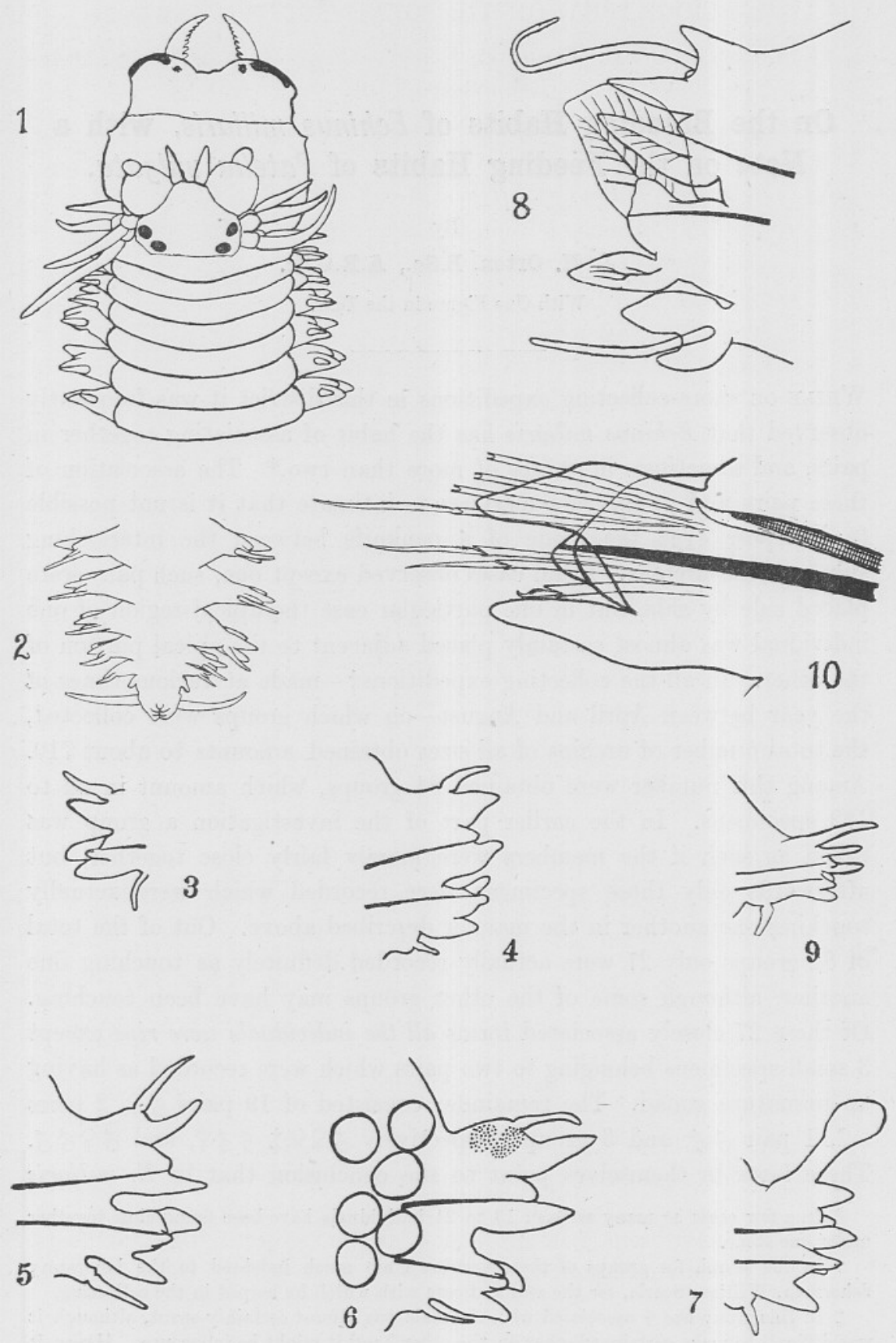

L.N.G.R. DEL. 